Jurnal Indonesia Sosial Teknologi: p-ISSN: 2723 - 6609

e-ISSN : 2745-5254

Vol. 2, No. 9 September 2021

\title{
PARTISIPASI WANITA BULAKREJO DALAM PROGRAM KRPL (KAWASAN RUMAH PANGAN LESTARI) KWT CENDANA KECAMATAN SUKOHARJO, KABUPATEN SUKOHARJO, JAWA TENGAH.
}

\author{
Aisha Wiranti Dian Pradipta ${ }^{1}$, Suwarto $^{2}$, Eny Lestari ${ }^{3}$. \\ Program Studi Penyuluhan dan Komunikasi Pertanian, Fakultas Pertanian, Universitas \\ Sebelas Maret \\ Email: aishawiranti123@student.uns.ac.id ${ }^{1}$, suwar_uns@yahoo.co.id ${ }^{2}$, \\ enylestari@staff.uns.ac.id ${ }^{3}$
}

\begin{abstract}
Abstrak
Badan Ketahanan Pangan Kabupaten Sukoharjo kembali mengembangkan Konsep Kawasan Rumah Pangan Lestari (KRPL) melalui pemberdayaan Kelompok Wanita Tani (KWT), dalam rangka mempercepat penganekaragaman pangan dan memperkuat ketahanan pangan masyarakat. Adanya anjuran pemanfaatan pekarangan sangatlah tepat untuk memenuhi pangan dan gizi keluarga, mengingat selama ini pekarangan dan lahan sekitar belum dimanfaatkan secara optimal. Perbaikan gizi keluarga sekaligus meningkatkan pendapatan keluarga. Manfaatnya sangat besar, terutama bagi masyarakat golongan ekonomi lemah. Untuk itu Pemerintah telah menganjurkan agar memanfaatkan setiap jengkal tanah termasuk lahan tidur, galengan, maupun tanah kosong yang tidak produktif. Potensi luas lahan pekarangan dan lahan sekitar tempat tinggal yang belum dimanfaatkan relatif besar untuk dapat dimanfaatkan sebagai sumber pangan keluarga. Penelitian ini bertujuan untuk mengetahui faktor-faktor pembentuk partisipasi wanita Bulakrejo terhadap program KRPL (Kawasan Rumah Pangan Lestari) dan menganalisis mengenai perbedaan partisipasi anggota KWT Cendana yang berdomisili jauh dengan pasar dibandingkan anggota yang berdomisili jauh dari pasar serta hubungan antara faktor pembentuk partisipasi dengan partisipasi program KRPL (Kawasan Rumah Pangan Lestari). Populasi dalam penelitian ini meliputi seluruh anggota KWT Cendana di Kelurahan Bulakrejo baik yang berada di RT 01, RT 02, dan RT 03. Responden yang diambil merupakan keseluruhan populasi yang ada dengan menggunakan teknik sensus yaitu 66 orang. Analisis data menggunakan lebar interval, analisis Rank Spearman dan Mann Whitney dengan program IBM SPSS Statistics 25. Hasil dan kesimpulan penelitian ini menunjukkan bahwa faktorfaktor yang berhubungan dengan partisipasi wanita Bulakrejo terhadap program KRPL (Kawasan Rumah Pangan Lestari) yaitu: pendidikan non formal dan waktu luang. Partisipasi pada tahap perencanaan memiliki tingkatan yang sangat jarang, tahap pelaksanaan berada pada kategori jarang, dan partisipasi pada tahap evaluasi pemanfaatan hasil berada pada kategori paling banyak yaitu tidak pernah. Faktorfaktor yang memiliki hubungan sangat signifikan dengan partisipasi yaitu pendidikan non formal. Faktor yang berhubungan signifikan dengan partisipasi adalah waktu luang, sedangkan yang tidak berhubungan signifikan yaitu umur, pendidikan formal, dan intensitas monitoring dan evaluasi dan tidak ada perbedaan paertisipasi wanita Bulakrejo yang jauh dengan pasar dan dekat dengan pasar.
\end{abstract}


Partisipasi Wanita Bulakrejo dalam Program KRPL (kawasan rumah pangan lestari) KTW Cendana Kecamatan Sukoharjo, Kabupaten Sukoharjo, Jawa Tengah.

Kata kunci: Participation; Women Farmers; Sukoharjo; Sustainable Food House Area.

\section{Abstract}

The Sukoharjo Regency Food Security Agency has again developed the Sustainable Food House Area Concept (KRPL) through the empowerment of the Women Farmers Group (KWT), in order to accelerate food diversification and strengthen community food security. The suggestion for the use of the yard is very appropriate to meet the family's food and nutrition, considering that so far the yard and the surrounding land have not been used optimally. in improving family nutrition while increasing family income. The benefits are enormous, especially for the economically weak. For this reason, the Government has recommended that every inch of land be utilized, including unused land, galengan, or unproductive vacant land. The potential area of the yard and land around the residence that has not been utilized is relatively large to be used as a source of family food. This study aims to determine the factors that shape the participation of women in Bulakrejo towards the KRPL program (Kewasan Rumah Pangan Lestari) and to analyze the differences in the participation of Cendana KWT members who live far from the market compared to members who live far from the market and the relationship between the factors forming participation and program participation. KRPL (Sustainable Food House Area). The population in this study includes all members of the Cendana KWT in Bulakrejo Village, both those in RT 01, RT 02, and RT 03. The respondents taken are the entire population using the census technique, namely 66 people. Data analysis used interval width, Rank Spearman and Mann Whitney analysis with IBM SPSS Statistics 25 program. The results showed that the factors related to the participation of Bulakrejo women in the KRPL program (Sustainable Food House Area) were: non-formal education and leisure time. Participation at the planning stage has a very rare level, the implementation stage is in the rare category, and participation in the evaluation stage of the utilization of results is in the highest category, namely never. Factors that have a very significant relationship with participation are non-formal education. Factors that have a significant relationship with participation are leisure time, while those that are not significantly related are age, formal education, and intensity of monitoring and evaluation and there is no difference in participation of bulakrejo women who are far from the market and close to the market.

Keywords: Participation; Women Farmers; Sukoharjo; Sustainable Food House Area.

\section{Pendahuluan}

Pertanian masih menjadi sumber mata pencaharian mayoritas angkatan kerja di Indonesia dengan data BPS (2020) sebesar 88,57\% untuk tahun 2020 yang mengalami kenaikan dari tahun lalu 2019 dengan jumlah 87,59\%. Seiring dengan berkembangnya era globalisasi, suatu bangsa dituntut mampu menyusun strategi pembangunan. Pembangunan dapat berupa pembangunan fisik maupun sumber daya lainnya yang mengarah pada perbaikan kondisi ekonomi masyarakat. Pembangunan ekonomi berkelanjutan sangatlah penting karena berhubungan erat dengan tingkat kesejahteraan masyarakat. Suatu negara dapat dikatakan maju apabila kesejahteraan sudah dapat dirasakan oleh sebagian besar warganya. 
Pembangunan pertanian bertujuan untuk meningkatkan pendapatan dan taraf hidup petani. Melibatkan istri dan melatih anak-anaknya yang sudah mulai beranjak remaja untuk terlibat dalam kegiatan usaha taninya (Elizabeth, 2008). Salah satu alternatif untuk melakukan pembangunan pertanian dengan meningkatkan ketahanan pangan masyarakat adalah mengoptimalkan potensi lahan pekarangan. Lahan pekarangan dapat dijadikan aset berharga bagi pengembang usaha tani skala rumah tangga dan mampu menciptakan ketahanan pangan di tingkat rumah tangga.

Kementerian Pertanian memanfaatkan potensi ini dalam kebijakan diversifikasi sektor pertanian. Program tersebut direalisasikan dalam peraturan Menteri Pertanian Nomor 43 Tahun 2009 tentang Gerakan Percepatan Penganekaragaman Konsumsi Pangan (GP2KP). Implementasi dari GP2KP diantaranya adalah optimalisasi lahan pekarangan melalui konsep Kawasan Rumah Pangan Lestari (KRPL). (Khoirunnisa, 2018) menyatakan bahwa prinsip dari KRPL yaitu dibangun dari kumpulan rumah tangga yang ramah lingkungan yang dirancang mampu mewujudkan kemandirian pangan melalui pemanfaatan pekarangan. Tidak hanya pemanfaatan pekarangan, kegiatan KRPL juga diarahkan untuk pemberdayaan kemampuan kelompok wanita membudayakan pola konsumsi pangan beragam, bergizi seimbang dan Aman

Kementerian Pertanian menginisiasi pemanfaatan pekarangan melalui konsep Rumah Pangan Lestari (RPL). Mendukung terbentuknya Kelompok Tani (poktan) dan Kelompok Wanita Tani (KWT), peran serta wanita tani tersebut belum dapat mongoptimalkan usaha yang dikelolanya. Karena, beberapa faktor sebagai berikut: (1) keterbatasan modal, (2) rendahnya kesadaran istri petani untuk bergabung ke dalam KWT, (3) kurangnya pembinaan dari pemerintah tentang pentingnya peran KWT dalam kehidupan petani

Partisipasi diprediksi akan terus berlanjut selama petani merasa puas atau diuntungkan dengan ikut serta dalam kegiatan tersebut (Irawan, 2011). Banyak faktor yang menentukan partisipasi petani dalam mengikuti suatu kegiatan, salah satu faktor yang paling penting dalam partisipasi adalah faktor dari dalam diri petani tersebut atau faktor internal. Faktor internal petani berhubungan dengan partisipasi petani yang nantinya akan menentukan tingkat partisipasinya sehingga ketika faktor-faktor tersebut ditemukan dalam lokasi kegiatan, maka hal itu dapat dijadikan acuan dalam meningkatkan tingkat partisipasinya.

Partisipasi diprediksi akan terus berlanjut selama petani merasa puas atau diuntungkan dengan ikut serta dalam kegiatan tersebut (Irawan, 2011). Banyak faktor yang menentukan partisipasi petani dalam mengikuti suatu kegiatan, salah satu faktor yang paling penting dalam partisipasi adalah faktor dari dalam diri petani tersebut atau faktor internal. Faktor internal petani berhubungan dengan partisipasi petani yang nantinya akan menentukan tingkat partisipasinya sehingga ketika faktor-faktor tersebut ditemukan dalam lokasi kegiatan, maka hal itu dapat dijadikan acuan dalam meningkatkan tingkat partisipasinya.

Menurut (Kurniawan, Hidayat, \& Amirudin, 2020) Partisipasi masyarakat merupakan keikutsertaan mereka dalam suatu kegiatan. Sependapat dengan definisi yang dikemukakan oleh (Nasdian, 2014) proses inisiatif secara aktif yang dilakukan warga komunitas itu sendiri yang dibimbing oleh cara berpikir mereka sendiri dengan 
menggunakan sarana dan proses (lembaga mekanisme) dimana menegaskan kontrol secara efektif.

Menurut (Syifa, Wijianto, \& Ihsaniyati, 2020) umur adalah jumlah tahun hidup petani yang bersangkutan dalam tahun dari individu tersebut lahir hingga penelitian dilakukan. Semakin bertambahnya umur, maka produktivitas seseorang akan menurun. Namun pada usia lanjut cenderung setia pada pekerjaan karena seseorang akan menganggap dan berpikir realistis bahwa pada usia tersebut produktivitas sudah menurun, maka akan menyesuaikan dengan kemampuan fisik dan keadaan ekonominya. Kelebihan lain dari usia lanjut antara lain akan lebih percaya diri karena berpengalaman dan lebih handal pada pekerjaannya.

Pendidikan formal merupakan pendidikan terakhir yang ditempuh petani yang bersangkutan selama hidupnya (Syifa et al., 2020). Pendidikan non formal merupakan keikutsertaan petani dalam kegiatan proses pembelajaran diluar pendidikan formal. Pendidikan non formal dapat dilakukan secara berstruktur dan berjenjang seperti pendidikan formal, namun pelaksanaanya diluar pendidikan formal.

Pekerjaan yang baik adalah yang dapat mencukupi kebutuhan sehari-hari sehingga dapat mendorong seseorang berpartisipasi dalam kegiatan bermasyarakat tanpa ada tuntutan untuk mempertahankan hidupnya. Partisipasi harus didukung dengan perekonomian yang mapan dan kebutuhan untuk menunjang kehidupannya dan kehidupan keluarga (BPS, 2019)

Menurut BPP Kaliasin (2016) bahwa Kelompok Wanita Tani (KWT) merupakan kumpulan wanita yang dibentuk oleh warga atau pemerintah yang dibina oleh Dinas Pertanian dan Industri untuk mencapai kesejahteraan sosial dan ekonomi sebagai bentuk peningkatan taraf kesejahteraan sosial melalui organisasi pemberdayaan masyarakat.

Kementerian Pertanian pada awal tahun 2011 menyusun suatu konsep yang disebut dengan Kawasan Rumah Pangan Lestari (KRPL). Prinsip dari M-KRPL yaitu pemanfaatan pekarangan yang dibangun dari kumpulan rumahtangga yang mampu mewujudkan kemandirian pangan untuk melakukan upaya diversifikasi pangan berbasis sumberdaya lokal sekaligus pelestarian tanaman pangan untuk masa depan, serta tercapainya upaya peningkatan kesejahteraan keluarga dan masyarakat. Kawasan Rumah Pangan Lestari (KRPL) menjadi salah satu bentuk pemberdayaan rumah tangga secara lestari dalam satu kawasan dengan tujuan menyediakan pangan keluarga yang beragam, bergizi, seimbang dan aman melalui teknologi, inovatif, diantaranya pengolahan kotoran ternak untuk pupuk, penggunaan sampah rumah tangga menjadi mikro organisme lokal (Departemen pertanian, 2011). Program rumah pangan lestari dikembangkan di Indonesia dengan harapan dapat mengatasi krisis pangan dunia serta dampak lonjakan harga pangan dunia dapat diminimalisir. Melibatkan rumah tangga dalam mewujudkan kemandirian pangan, diversifikasi pangan berbasis sumberdaya lokal, dan konservasi tanaman pangan untuk masa depan perlu diaktualisasikan dalam menggerakan lagi budaya menanam di lahan pekarangan, baik di perkotaan maupun perdesaan. (Badan Litbang Pertanian, 2012). 
Penyuluhan pertanian berperan penting bagi pembangunan pertanian, sebab penyuluhan merupakan salah satu upaya pemberdayaan pertani dan pelaku usaha pertanian lain untuk meningkatkan produktivitas, pendapatan, dan kesejahteraanya. Kegiatan penyuluhan pertanian harus dapat mengakomodasi aspirasi dan peran aktif petani dan pelaku usaha pertaniannya melalui pendekatan partisipatif (Sagita, Akhbar, \& Muis, 2019) Memperbaiki kesejahteraan hidup petani dan keluarganya tanpa merusak lingkungan merupakan hal yang penting dalam memberikan modal dalam penyuluhan pertanian (Koampa, Benu, Sendow, \& Moniaga, 2015). Kegiatan penyuluh yang digunakan untuk proses belajar melalui pendekatan kelompok yang diarahkan untuk mewujudkan kemampuan kerjasama yang lebih efektif. Menerapkan inovasi sehingga mampu mengatasi berbagai resiko kegagalan, skala ekonomis untuk memperoleh pendapatan yang layak. Kesadaran akan peran dan tanggungjawab juga menjadi hal yang krusial sebagai pelaku pembangunan terkhusus pembangunan pertanian (Ardika, 2016).

Penelitian ini dirasa cukup penting dikarenakan partisipasi yang dilakukan oleh anggota KWT (Kelompok Wanita Tani) Cendana yang berfokus pada pertahanan pangan dalam skala rumah tangga sangat membantu dalam keadaan sekarang saat pandemi Covid19 ini terjadi. Ketika ketahanan pangan pada tingkat rumah tangga dapat kuat, maka ketahanan pangan pada tingkat nasional dapat diraih

\section{Metode Penelitian}

Metode penelitian ini menggunakan metode penelitian kuantitaif yaitu metode penelitian yang berlandaskan filsafat positivistik/asumsi bahwa suatu gejala dapat diklasifikasikan dan pengaruh gejala bersifat sebab akibat. Peneliti dapat melakukan penelitian dengan memfokuskan pada beberapa variabel saja, yang digunakan untuk meneliti pada populasi dan sampel tertentu. Pengumpulan data menggunakan instrumen penelitian, analisis data bersifat kuantitatif, dengan untuk menguji hipotesis yang telah ditetapkan (Sugiyono, 2018).

Penelitian ini terdiri dari variabel faktor internal umur, pendidikan formal, pendidikan non formal, waktu luang, jarak rumah dengan pasar. Faktor Eksternal yaitu Intensitas Monitoring PPL sebagai variabel bebas dengan tahap partisipasi dalam tahap perencanaan, pelaksaaan, evaluasi \& pemanfaatan hasil sebagai variabel terikat. Penelitian ini menggunakan teknik sensus sebanyak 66 orang anggota KWT Cendana. Analisis data dengan menggunakan Korelasi Rank Spearman dan Uji Beda Mann Whitney. Menurut (Sugiyono, 2018), korelasi Rank Spearman digunakan untuk mencari hubungan atau untuk menguji signifikasi hipotesis asosiatif bila masing masing variabel yang dihubungkan berbentuk ordinal, dan sumber data antar variabel tidak harus sama yang didukung dengan program SPSS 25 for windows.

\section{Hasil dan Pembahasan}

\section{A. Usia}


Didapatkan hasil paling besar menunjukkan pada umur 42 tahun sampai dengan umur 49 tahun dengan jumlah anggota sebanyak 23 orang dan prosentase sebesar 34,84. Hal ini dikarenakan anggota KWT Cendana merupakan wanita yang masih tergolong usia produktif yang juga tergabung kedalam anggota organisasi PKK (Pengembangan Kesejahteraan Keluarga) yang sudah pasti merupakan wanita yang sudah berkeluarga. Jadi, tidak mungkin terdapat anggota yang dibawah umur 20 tahun maupun seorang siswa.

\section{B. Pendidikan Formal}

Responden tingkat pendidikan formal responden dalam penelitian ini bervariasi, mulai dari SD hingga Perguruan Tinggi, namun tidak ada responden yang tidak mengenyam pendidikan. Pendidikan terakhir responden paling banyak yaitu tamatan SMA sebanyak 35 orang dan presentasenya sebesar 53,04.

\section{Pendidikan Non Formal}

Pendidikan non formal anggota KWT Cendana berada pada tingkat sangat jarang dimana kebanyakan anggota KWT Cendana tidak menghadiri untuk mengikuti pendidikan formal yang diselenggarakan baik penyuluhan pertanian, kursus pertanian, dan adanya studi banding yang ada. Hasil menunjukkan angka sebanyak 35 orang anggota dan prosentase sebesar 53,03

\section{Waktu Luang}

Hasil terbanyak menunjukkan bahwa anggota KWT Cendana merasa memiliki waktu luang yang sedikit dan tergolong sibuk dengan jumlah 35 orang dan prosentase sebanyak 53,04. Sebagian besar anggota KWT Cendana merupakan IRT (Ibu Rumah Tangga) yang tidak bekerja namun memiliki sampingan berdagang. Namun, saat dilakukannya wawancara, dengan status mereka sebagai ibu rumah tangga yang tidak terikat instansi manapun menjadikan jam kerja mereka serasa 24 jam dikarenakan urusan rumah tangga seperti kebersihan, memasak makanan, dan hal-hal yang berkaitan dengan rumah menjadi tanggungjawab wanita sepenuhnya sehingga mengurangi kesempatan untuk dapat berpartisipasi lebih didalam KWT Cendana

\section{E. Tingkat Perencanaan}

Diketahui bahwa anggota sangat jarang mengikuti pada tahap perencanaan dengan jumlah anggotanya 25 orang dan prosentase sebesar 37,88. Hal ini terjadi dikarenakan setiap anggota KWT Cendana memiliki kesibukan seperti bekerja, keperluan pribadi yang tidak bisa ditinggal, dan adanya batasan kapasitas audiens pada setiap acara yang diselenggarakan. Pembatasan disini berarti dalam satu acara, hanya mempunyai kuota tertentu untuk kehadiran dalam acara. Menurut (Syarief \& Rangga, 2018), tingkat partisipasi petani dalam perencanaan dilihat dari, intensitas pertemuan yang diikuti oleh petani, keinginan petani untuk mempersiapkan dan mengumpulkan data dari program tersebut, dan keinginan petani dalam memberikan masukan dan 
mengidentifikasi masalah yang terjadi pada program tersebut. Menurut (Syarief \&

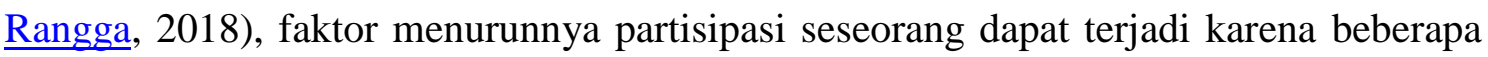
kegiatan yang dilakukan diawal sudah tidak rutin lagi dilaksanakan, dan adanya kegiatan lain atau kegiatan baru yang dilakukan sehingga menggangu proses partisipasi pada program tersebut.

\section{F. Tingkat Pelaksanaan}

Didapatkan hasil bahwa untuk tahap pelaksanaan partisipasi anggota KWT Cendana masih jarang dengan 21 orang sebanyak 31,82. Hal ini tidak lepas dari kesibukan masing-masing anggota. Antisipasi yang telah dilakukan dengan sistem penjadwalan piket untuk anggota dapat melaksanakan selama satu mingu sekali dengan menggantinya dilain hari yang senggang sehingga para anggota tetap dapat melaksanakan tugas yang ada sesuai giliran.

\section{G. Tingkat Evaluaasi dan Pemanfatan Hasil}

Didapatkan hasil bahwa untuk tahap evaluasi partisipasi anggota KWT Cendana berada dikategori yang tidak pernah sebanyak 36 orang dengan prosentase sebesar 54,55 . Hal ini dikarenakan terkadang hasil panen yang langsung dibagi dan dirasakan oleh anggota, kondisinya kurang baik jika harus disimpan atau dimanfaatkan kembali, lebih baik dibuang, dan anggota yang tidak dapat menghadiri kegiatan panen yang diselenggarakan

\section{H. Tingkat Partisipasi Anggota KWT Cendana}

Adapun hasil keseluruhan mengenai kategori partisipasi KWT Cendana berkaitan dengan program KRPL (Kawasan Rumah Pangan Lestari) yang berjalan selama tiga tahun ini adalah cukup.

Tingkat partisipasi anggota KWT Cendana terhadap program KRPL (Kawasan Rumah Pangan Lestari) dapat dikatakan pada kategori cukup baik yang ditunjukkan dengan prosentase $46,97 \%$. Adapun kategori tinggi ialah adanya partisipasi yang aktif dalam kegiatan seperti membuat perencanaan kegiatan, adanya keterlibatan dalam pelaksanaan kegiatan, dan dapat merasakan manfaat dari berpartisipasi pada kegiatan tersebut (Rangga, Darsono, Anantanyu, \& Wijaya, 2014).

Hubungan Faktor-Faktor Pembentuk Persepsi dengan Persepsi Pemuda terhadap Pekerjaan Petani Di Kecamatan Sumberlawang Kabupaten Sragen

\begin{tabular}{llcc}
\hline No & $\begin{array}{c}\text { Faktor } \\
\text { Pembentuk } \\
\text { partisipasi } \\
(\mathrm{X})\end{array}$ & $\begin{array}{c}\text { Partisipasi } \\
\text { Program KRPL } \\
(\text { Y total })\end{array}$ & Keterangan \\
\cline { 3 - 4 } 1. & umur (X1) & 0,755 & TS \\
\hline 2. & $\begin{array}{l}\text { Pendidikan } \\
\text { Formal }\end{array}$ & 0,916 & TS \\
\hline
\end{tabular}


Partisipasi Wanita Bulakrejo dalam Program KRPL (kawasan rumah pangan lestari) KTW Cendana Kecamatan Sukoharjo, Kabupaten Sukoharjo, Jawa Tengah.

\begin{tabular}{|c|c|c|c|c|}
\hline & (X2) & & & \\
\hline 3. & $\begin{array}{l}\text { Pendidikan } \\
\text { non } \\
\text { Formal } \\
\text { (X3) }\end{array}$ & 0,000 & & SS \\
\hline 4. & $\begin{array}{l}\text { Waktu } \\
\text { Luang } \\
(\mathrm{X} 4)\end{array}$ & 0,002 & $\mathrm{~S}$ & \\
\hline 5. & $\begin{array}{l}\text { Intensitas } \\
\text { Monitoring } \\
\text { PPL (X5) }\end{array}$ & 0,830 & $\mathrm{TS}$ & \\
\hline
\end{tabular}

1. Hubungan antara umur dengan partisipasi Anggota

Tabel menunjukkan bahwa tidak terdapat hubungan yang signifikan antara umur dengan partisipasi wanita Bulakrejo terhadap program KRPL. Tabel tersebut menunjukkan nilai koefisien korelasi rank spearman (rs) yaitu sebesar $(-0,039)$ dengan sig. (2-tailed) sebesar $(0,755)$ dan dengan $\alpha(0,05)$, pada taraf signifikasi $95 \%$. Hal ini berarti menunjukkan bahwa $\alpha(0,05), \leq$ sig. (2-tailed) sebesar $(0,755)$. Dimana Ho diterima dan ha ditolak, yang artinya tidak terdapat hubungan yang signifikan antara umur dengan partisipasi wanita Bulakrejo terhadap Program KRPL (Kawasan Rumah Pangan Lestari). Selaras dengan penelitian (Yantari, 2020) Rentang usia produktif kurag dari 64 tahun, sehingga penduduk atau kelompok wanita tani tidak semuanya dapat menerima dengan mudah inovasi yang diberikan dalam program Kawasan Rumah Pangan Lestari dan mampu mengaplikasikan inovasi tersebut dalam usaha tani mereka. Hal ini disebabkan karena anggota memiliki kurangnya pengetahuan mengenai pertanian dan kesadaran pentingnya program KRPL sehingga tidak dapat menyerap apa yang diberikan secara maksimal

2. Hubungan antara Pendidikan Formal dengan Partisipasi Anggota

Berdasarkan tabel hasil analisis menunjukkan bahwa pendidikan formal tidak terdapat hubungan yang signifikan antara pendidikan formal dengan partisipasi wanita anggota KWT Cendana terhadap Program KRPL (Kawasan Rumah Pangan Lestari). Tabel tersebut menunjukkan nilai koefisien korelasi rank spearman (rs) yaitu sebesar $(0,013)$ dengan sig. (2-tailed) sebesar $(0,916)$ dengan $\alpha(0,05)$, pada taraf signifikasi 95\%. ). Dimana Ho diterima dan ha ditolak, yang artinya tidak terdapat hubungan yang signifikan antara pendidikan formal dengan partisipasi wanita Bulakrejo terhadap Program KRPL (Kawasan Rumah Pangan Lestari). Nilai rs $\left(0,013^{*}\right)$, termasuk pada kategori sangat lemah dengan arah hubungan positif (+) atau tidak berlawanan arah.

\section{Hubungan antara Pendidikan non formal dengan Partisipasi Anggota}

Tabel menunjukkan bahwa terdapat hubungan yang signifikan antara pendidikan non formal dengan partisipasi wanita anggota KWT Cendana terhadap Program KRPL (Kawasan Rumah Pangan Lestari). Tabel tersebut menunjukkan nilai koefisien korelasi rank spearman (rs) yaitu sebesar $(0,491 *)$ dengan sig. (2-tailed) sebesar $(0,000)$ dengan $\alpha(0,05)$, pada taraf signifikasi $95 \%$. ). Dimana Ho ditolak dan ha diterima, yang artinya 
terdapat hubungan yang sangat signifikan antara pendidikan non formal dengan partisipasi wanita Bulakrejo terhadap Program KRPL (Kawasan Rumah Pangan Lestari). Nilai rs $\left(0,491^{*}\right)$, termasuk pada kategori cukup kuat dengan arah hubungan positif (+) atau tidak berlawanan arah. Hubungan tersebut memiliki arti bahwa semakin seringnya anggota KWT Cendana mengikuti pendidikan non formal, memiliki hubungan yang sangat signifikan dengan baiknya partisipasi anggota KWT Cendana terhadap Program KRPL (Kawasan Rumah Pangan Lestari). Menurut Hanafiah (2013), Dengan intensitas pelatihan rendah, kompetensi yang sedang atau kurang kompeten dan tingkat motivasi yang relatif cukup atau biasa saja serta proses penyuluhan yang dilakukan seadanya tanpa dukungan sarana dan prasarana yang memadai maka sudah dipastikan peningkatan pengetahuan petani yang dicapai rendah.

\section{Hubungan antara Waktu Luang dengan Partisipasi Anggota}

Data pada tabel menunjukkan bahwa terdapat hubungan yang signifikan antara waktu luang dengan partisipasi wanita anggota KWT Cendana terhadap Program KRPL (Kawasan Rumah Pangan Lestari). Tabel tersebut menunjukkan nilai koefisien korelasi rank spearman (rs) yaitu sebesar $(-0,374 *)$ dengan sig. (2-tailed) sebesar $(0,002)$ dengan $\alpha(0,05)$, pada taraf signifikasi $95 \%$. ). Dimana Ho ditolak dan ha diterima, yang artinya terdapat hubungan yang signifikan antara waktu luang dengan partisipasi wanita Bulakrejo terhadap Program KRPL (Kawasan Rumah Pangan Lestari). Nilai rs $\left(0,374^{*}\right)$, termasuk pada kategori cukup dengan arah hubungan negatif (-) atau berlawanan arah. Hubungan tersebut memiliki arti bahwa semakin tinggi kesibukan yang dimiliki anggota KWT Cendana maka semakin buruk partisipasi yang diberikan untuk kegiatan KWT Cendana terhadap Program KRPL (Kawasan Rumah Pangan Lestari). Layard dan Walters (1978), menyebutkan bahwa keputusan individu untuk menambah atau mengurangi waktu luang dipengaruhi oleh tingkat upah dan pendapatan non kerja. Adapun tingkat produktivitas selalu berubah-rubah sesuai dengan fase produksi dengan pola mula-mula naik mencapai puncak kemudian menurun. Jam kerja berpengaruh positif meningkatkan pendapatan pekerja hal ini disebabkan oleh pembagian waktu luang dan waktu bekerja.

5. Hubungan antara Intensitas monitoring dan evaluasi PPL (Penyuluh Pertanian Lapang) dengan Partisipasi Anggota

Hasil analisis pada tabel, dapat diketahui bahwa tidak terdapat hubungan yang signifikan antara intensitas monitoring dan evaluasi yang dilakukan oleh PPL (Penyuluh Pertanian Lapang) dengan partisipasi wanita anggota KWT Cendana terhadap Program KRPL (Kawasan Rumah Pangan Lestari). Tabel tersebut menunjukkan nilai koefisien korelasi rank spearman (rs) yaitu sebesar $(0,830)$ dengan sig. (2-tailed) sebesar $(0,830)$ dengan $\alpha(0,05)$, pada taraf signifikasi 95\%. ). Dimana Ho diterima dan ha ditolak, yang artinya tidak terdapat hubungan yang signifikan antara intensitas monitoring dan evaluasi dari PPL (Penyuluh Pertanian Lapang) dengan partisipasi wanita Bulakrejo terhadap Program KRPL (Kawasan Rumah Pangan Lestari). 
Partisipasi Wanita Bulakrejo dalam Program KRPL (kawasan rumah pangan lestari) KTW Cendana Kecamatan Sukoharjo, Kabupaten Sukoharjo, Jawa Tengah.

Perbedaan Jarak Rumah dengan Partisipasi Anggota

\begin{tabular}{lcccccc}
\hline \hline Jarak & $\mathbf{N}$ & $\begin{array}{c}\text { Mean } \\
\text { Rank }\end{array}$ & $\begin{array}{c}\text { Sum of } \\
\text { Rank }\end{array}$ & $\begin{array}{c}\text { Mann } \\
\text { Whitney }\end{array}$ & $\begin{array}{c}\text { Asymp.sig } \\
\text { (2-tailed) }\end{array}$ & Zhit \\
$\mathbf{1}$ & $\mathbf{2}$ & $\mathbf{3}$ & $\mathbf{4}$ & $\mathbf{5}$ & $\mathbf{6}$ & $\mathbf{7}$ \\
Jauh Pasar & 59 & 35.79 & 250.50 & 190.500 & 0.738 & -0.335 \\
Dekat Pasar & 7 & 33.23 & 1960.50 & & & \\
\hline \hline
\end{tabular}

Berdasarkan data pada tabel dapat diketahui bahwa anggota KWT Cendana sebanyak 59 orang memiliki jarak yang jauh dengan pasar yaitu Pasar Ir. Soekarno Sukoharjo yang dari kelurahan Bulakrejo berjarak kurang lebih 3 Kilometer. Anggota KWT Cendana lainnya berjumlah 7 orang memilih untuk membeli di warung kelontong milik warga dikarenakan efisiensi waktu dan jarak yang harus ditempuh. Jumlah ratarata terbanyak wanita Bulakrejo yang menjadi anggota KWT Cendana berada pada RT (Rukun Tetangga) 01 dibandingkan dengan RT lainnya (RT 01, RT 02, dan RT 04). Nilai Zhitung uji Mann Whitney perbedaan jarak rumah dengan pasar sebesar -0,335 dengan nilai signifikansi 0,738 . Nilai signifikansi $(\alpha=0,05)$, maka keputusan uji adalah H0 diterima dengan kesimpulan bahwa tidak terdapat perbedaan partisipasi anggota KWT Cendana berdasarkan jarak rumah dengan pasar. Hal ini bertentangan dengan penelitian yang dilakukan oleh (Wiyasa \& Dewi, 2017), penelitian mengenai faktorfaktor yang mempengaruhi curahan jam kerja bahwa penghasilan ibu rumah tangga sangat mempengaruhi intensitas kerja ibu rumah tangga tersebut. Begitupula dengan jumlah tanggungan keluarga, jarak rumah dengan pasar tempat kerja merupakan faktor potensial bagi pekerja dalam bekerja yang juga akan mempengaruhi intensitas kerja seseorang. Menurut (Kusumastuti \& Purwanti, 2012), Jarak tempat tinggal responden ke tempat bekerja merupakan jarak yang harus ditempuh responden menuju tempat bekerja. Semakin jauh jaraknya maka waktu yang terbuang semakin banyak, tingkat efisiensi waktu menurun. Akibatnya curahan jam kerja akan semakin berkurang.

\section{Kesimpulan}

Berdasarkan hasil penelitian, analisis hasil, dan pembahasan, maka dapat diambil beberapa kesimpulan antara lain:

a. Faktor pembentuk partisipasi anggota terhadap program KRPL (Kawasan Rumah Pangan Lestari) di Kecamatan Sukoharjo, Kabupaten Sukoharjo dapat diketahui sebagai berikut:

a) Umur tergolong sedang dengan rata-rata anggota berumur 42-49 tahun

b) Pendidikan formal anggota KWT Cendana tergolong tinggi dengan jumlah terbanyak merupakan tamatan SMA (Sekolah Menengah Atas)

c) Pendidikan non formal tergolong sangat jarang

d) waktu luang yang dimiliki anggota tergolong pada kategori sibuk

e) intensitas monitoring dan evaluasi PPL berada pada kategori sangat jarang

f) jarak rumah dengan pasar termasuk dalam kategori jauh

b. Faktor-faktor yang memiliki hubungan dengan partisipasi yaitu pendidikan nnformal dan waktu luang. Sedangkan yang tidak memiliki hubungan signifikan yaitu umur, pendidikan formal, dan intensitas monitoring dan evaluasi PPL (Penyuluh Pertanian Lapang) 


\section{Bibliografi}

Elizabeth, Roosganda. (2008). Peran ganda wanita tani dalam mencapai ketahanan pangan rumah tangga di pedesaan.

Irawan, Evi. (2011). Prospek partisipasi petani dalam program pembangunan hutan rakyat untuk mitigasi perubahaan iklim di wonosobo. Jurnal Ekonomi Pembangunan: Kajian Masalah Ekonomi Dan Pembangunan, 12(1), 67-76. https://doi.org/10.23917/jep.v12i1.206

Khoirunnisa, Ana. (2018). Evaluasi Program Kawasan Rumah Pangan Lestari (KRPL) Kelompok Wanita Tani Kecamatan Seminkabupaten Gunung Kidul.

Koampa, Mario Victorya, Benu, Olfie L. S., Sendow, Martha M., \& Moniaga, Vicky R. B. (2015). Partisipasi Kelompok Tani dalam Kegiatan Penyuluhan Pertanian di Desa Kanonang Lima, Kecamatan Kawangkoan Barat, Minahasa. AgriSosioekonomi, 11(3A), 19-32. https://doi.org/10.35791/agrsosek.11.3A.2015.10294

Kurniawan, Andi, Hidayat, J. W., \& Amirudin, Amirudin. (2020). Partisipasi Masyarakat: Mendukung Keberhasilan Pengelolaan Hutan Rakyat. Seminar Nasional Lahan Suboptimal, (1), 93-102.

Kusumastuti, Nanda Ayu, \& Purwanti, Evi Yulia. (2012). Pengaruh faktor pendapatan, umur, jumlah tanggungan keluarga, pendapatan suami dan jarak tempuh ke tempat kerja terhadap curahan jam kerja pedagang sayur wanita (studi kasus di Pasar Umum Purwodadi). Fakultas Ekonomika dan Bisnis.

Nasdian, Fredian Tonny. (2014). Pengembangan masyarakat. Yayasan Pustaka Obor Indonesia.

Rangga, Kordiyana, Darsono, Darsono, Anantanyu, Sapja, \& Wijaya, Mahendra. (2014). The Participation of Micro Business Affinity Group Members in the Implementation of Food Self-Sufficiency Action Program in Lampung Province. Academic Research International, 5(3), 112-122.

Sagita, Merki Natasya, Akhbar, Akhbar, \& Muis, Hasriani. (2019). Partisipasi Petani Dalam Pengelolaan Hutan Kemasyarakatan Di Desa Labuan Toposo Kecamatan Labuan Kabupaten Donggala. Jurnal Warta Rimba, 7(2).

Sugiyono. (2018). Metode Penelitian Kuantitatif, Kualitatif, dan R\&D. Bandung: Alfabeta.

Syarief, Yuniar Aviati, \& Rangga, Kordiyana. (2018). Paddy farmer households' participation and food security level in special effort program in Seputih Raman Sub-district of Central Lampung Regency. IOP Conference Series: Earth and 
Partisipasi Wanita Bulakrejo dalam Program KRPL (kawasan rumah pangan lestari) KTW Cendana Kecamatan Sukoharjo, Kabupaten Sukoharjo, Jawa Tengah.

Environmental Science, 142(012060), 1-5. IOP Publishing Ltd.

Syifa, Salsabila Hanandita, Wijianto, Arip, \& Ihsaniyati, Hanifah. (2020). Tingkat Partisipasi Petani dalam Demonstrasi Area Budidaya Tanaman Sehat Padi di Kabupaten Boyolali. Prosiding Ilmu Ilmu Peternakan.

Wiyasa, Ida Bagus Windu, \& Dewi, Made Heny Urmila. (2017). Faktor-Faktor Yang Mempengaruhi Pendapatan Melalui Curahan Jam Kerja Ibu Rumah Tangga Pengrajin Bambu Di Kabupaten Bangli. PIRAMIDA.

Yantari, Margareta. (2020). Penguatan Partisipasi Anggota Kelompok Wanita Tani (Kwt) Organa Gardenia Dalam Program Kawasan Rumah Pangan Lestari (Krpl) Di Kelurahan Nusukan, Kecamatan Banjarsari, Surakarta. 